量

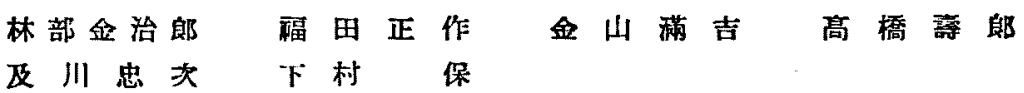
括

里

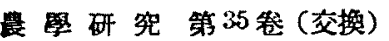

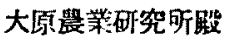

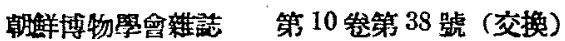

朝鮮抵物學會收

むし 第 15 第 $1 / 2$ 唬(交換)

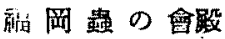

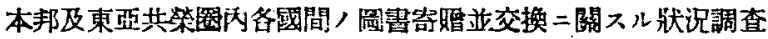

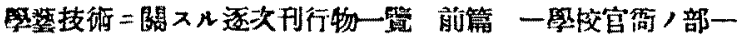
旁國圆 書 師殿

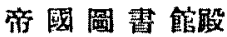

\title{
正 铞
}

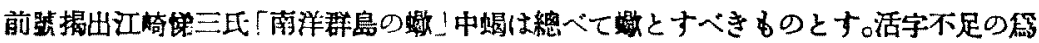

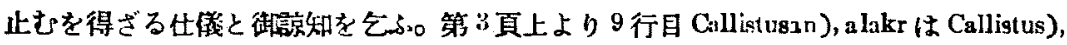

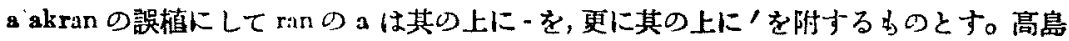

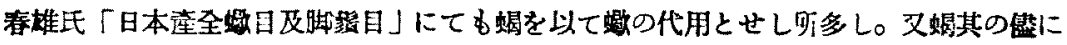

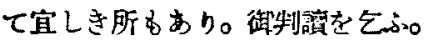

\begin{tabular}{|c|c|c|c|}
\hline 頁 & $\hat{\mathrm{T}}$ & 譔 & 正 \\
\hline 13 & -8 & 1755 & $17 \div 5$ \\
\hline 16 & +5 & 趾璟 & 跱距 \\
\hline 19 & -3 & 蹠䇴 & 脛勔 \\
\hline 22 & +3 & 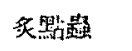 & 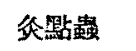 \\
\hline 25 & -6 & 第 2 批脚 & 第 1 步脚 \\
\hline 26 & +12 & 數侧 & 數侹 \\
\hline 29 & +12 & 4 figs, & 4 figs., \\
\hline$"$ & -10 & Pcdipalpi & Pedipalpi. \\
\hline$"$ & -7 & Tierreicts & Tierreicks \\
\hline
\end{tabular}

今年 6 月 21 日以降 11 月林日までに次の方々から會費を頂戴致しました。拜領順に芳 名を銫して一↔の受領證に代へます。

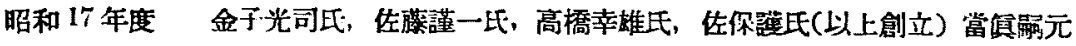

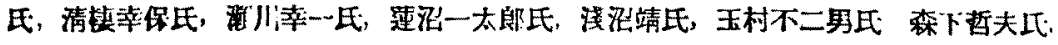

